\title{
Developmental Methamphetamine Exposure Results in Short- and Long-Term Alterations in Hypothalamic-Pituitary-Adrenal-Axis-Associated Proteins
}

\author{
Damian G. Zuloaga a Jessica A. Siegel ${ }^{\mathrm{a}}$ Summer F. Acevedo ${ }^{\mathrm{a}}$ Maayan Agam ${ }^{\mathrm{a}}$ \\ Jacob Raber ${ }^{a-c}$
}

Departments of ${ }^{\mathrm{a} B e h a v i o r a l ~ N e u r o s c i e n c e ~ a n d ~}{ }^{\mathrm{b}}$ Neurology, Division of Neuroscience, and ${ }^{\mathrm{c} O N P R C,}$ Oregon Health and

Science University Portland, Portland, OR., USA

\section{Key Words \\ Methamphetamine exposure - Behavioral and cognitive deficits · Hypothalamic-pituitary-adrenal-axis-associated proteins}

\begin{abstract}
Developmental exposure to methamphetamine (MA) causes long-term behavioral and cognitive deficits. One pathway through which MA might induce these deficits is by elevating glucocorticoid levels. Glucocorticoid overexposure during brain development can lead to long-term disruptions in the hypothalamic-pituitary-adrenal (HPA) axis. These disruptions affect the regulation of stress responses and may contribute to behavioral and cognitive deficits reported following developmental MA exposure. Furthermore, alterations in proteins associated with the HPA axis, including vasopressin, oxytocin, and glucocorticoid receptors (GR), are correlated with disruptions in mood and cognition. We therefore hypothesized that early MA exposure will result in short- and long-term alterations in the expression of HPA axis-associated proteins. Male mice were treated with MA ( $5 \mathrm{mg} / \mathrm{kg}$ daily) or saline from postnatal day (P) 11 to P20. At P20 and P90, mice were perfused and their brains processed for vasopressin, oxytocin, and GR immunoreactivity within HPA axis-asso-
\end{abstract}

ciated regions. At P20, there was a significant decrease in the number of vasopressin-immunoreactive cells and the area occupied by vasopressin immunoreactivity in the paraventricular nucleus (PVN) of MA-treated mice, but no difference in oxytocin immunoreactivity in the PVN, or GR immunoreactivity in the hippocampus or PVN. In the central nucleus of the amygdala, the area occupied by GR immunoreactivity was decreased by MA. At P90, the number of vasopressin-immunoreactive cells was still decreased, but the area occupied by vasopressin immunoreactivity no longer differed from saline controls. No effects of MA were found on oxytocin or GR immunoreactivity at $\mathrm{P} 90$. Thus developmental MA exposure has short- and long-term effects on vasopressin immunoreactivity and short-term effects on GR immunoreactivity.

Copyright $\odot 2013$ S. Karger AG, Basel

\section{Introduction}

The psychostimulant methamphetamine (MA) is abused by approximately 1.2 million individuals over the age of 12 [1]. As a result, women that abuse MA might do so while pregnant. Exposure to MA in utero can lead to behavioral and cognitive deficits [2] by altering the normal trajectory of brain development $[3,4]$.

\section{KARGER}

E-Mail karger@karger.com

www.karger.com/dne
(C) 2013 S. Karger AG, Basel

0378-5866/13/0354-0338\$38.00/0 
One pathway through which MA might induce detrimental effects is by activating the hypothalamic-pituitaryadrenal (HPA) axis. MA administered both neonatally and in adulthood has been demonstrated to cause large and prolonged increases in adrenocorticotropic hormone and corticosterone [5-9]. Exposure to high levels of glucocorticoids in early development can lead to long-term disruptions of the HPA axis. In rats, exposure to MA from postnatal day $(\mathrm{P}) 11$ to $\mathrm{P} 20$, a critical period for hippocampal development, results in blunted corticosterone responses to stress in adulthood. Developmental glucocorticoid overexposure has also been shown to lead to cognitive deficits in both humans and rodents $[10,11]$.

Elevated glucocorticoid levels alter brain development through several mechanisms including: decreasing cell proliferation [12], increasing cell death [13, 14], and altering the pattern of cell migration and differentiation $[15$, 16]. Developmental glucocorticoid exposure also alters the expression of genes associated with HPA axis function including the glucocorticoid receptor (GR) and vasopressin in pertinent brain regions such as the paraventricular nucleus (PVN), central nucleus of the amygdala, and hippocampus [17-19]. Similarly, neonatal stress, which causes the release of glucocorticoids, results in alterations in vasopressin and oxytocin cell number in the PVN [20]. These changes correlate with a long-term dysregulation of HPA axis function and stress-related behaviors $[18,21,22]$. GR, vasopressin, and oxytocin have each been implicated in the regulation of cognitive functions, particularly those related to hippocampal functions such as memory [23-25], indicating that glucocorticoid-induced deficits in cognition may be associated with alterations in the expression of these proteins.

Similar to glucocorticoid overexposure, MA exposure during development can lead to lasting alterations of HPA axis function and cognition $[6,26,27]$. However, the underlying mechanisms are unknown. In this study, we tested the hypothesis that exposure to MA from P11 to P20 will induce acute elevations in glucocorticoid levels and cause short- and long-term alterations in the expression of vasopressin, oxytocin, and GR in HPA axis-associated brain regions (PVN, central nucleus of the amygdala, and hippocampus). This treatment period corresponds to a late gestational development period in humans and is a critical time for development of HPA axis-associated brain regions, particularly the hippocampus $[28,29]$. Alterations in the expression of vasopressin, oxytocin and GR may contribute to deficits in stress-related and cognitive functions reported in rodents treated with MA during brain development [30-32].

Methamphetamine HPA Axis

\section{Methods}

\section{Animals}

C57BL/6J mice used for breeding of the mice used in this study were purchased from JAX Laboratories (Bar Harbor, Me., USA). The mice were bred under conditions of a 12-hour light/12-hour dark cycle with lights on at 6:00 a.m. Rodent chow (PicoLab Rodent Diet 20, \#5053; PMI Nutrition International, St. Louis, Mo., USA) and water were available ad libitum. Male mice were injected daily at 10:00 a.m. from P11 to P20 with D-MA hydrochloride dissolved in saline ( $5 \mathrm{mg} / \mathrm{kg}$ daily, i.p.) or saline alone (injection volume approx. $0.1 \mathrm{ml}$ ). Male pups from a total of 16 litters of C57BL/6J mouse pups were used in this study. Litter sizes of 2-6 pups were injected using a within-litter design to balance the number of distinct treatment injections within a litter and across sexes. Every litter had up to $4 \mathrm{MA}$-injected pups per litter. This dose was chosen because previous studies in our laboratory have shown that it causes significant increases in corticosterone in neonatal mice [5]. Furthermore, we chose the P11-20 treatment period because previous studies in our laboratory have demonstrated that exposure to $5 \mathrm{mg} / \mathrm{kg}$ MA during this developmental phase results in lasting functional impairments including deficits in learning and memory, circadian function, and sensorimotor gating $[27,32,33]$. On P20 (saline, $\mathrm{n}=5 ; \mathrm{MA}, \mathrm{n}=6$ ) and P90 (saline, $\mathrm{n}=7 ; \mathrm{MA}, \mathrm{n}=4$ ), mice were intracardially perfused with $20 \mathrm{ml}$ phosphate-buffered saline (PBS) followed by $40 \mathrm{ml} 4 \%$ paraformaldehyde. Brains were removed and stored in $30 \%$ sucrose. P20 mice were killed $1 \mathrm{~h}$ after the final injection. P20 brains were frozen in O.C.T. compound (Tissue-Tek, Torrance, Calif., USA) and stored at $-80^{\circ} \mathrm{C}$ prior to sectioning while $\mathrm{P} 90$ brains were sectioned following removal from $30 \%$ sucrose.

\section{Blood Collection and Corticosterone Assay}

Sixty, 120, and $240 \mathrm{~min}$ following $5 \mathrm{mg} / \mathrm{kg}$ MA or saline injections, P11 male mice ( $\mathrm{n}=4-9$ mice/treatment) were decapitated and trunk blood was collected into heparinized tubes (Baxter, McGaw Park, Ill., USA). The blood was spun at $10,000 \mathrm{~g}$ for $10 \mathrm{~min}$ at $4^{\circ} \mathrm{C}$, and the supernatant was transferred to a new tube and stored at $-70^{\circ} \mathrm{C}$ until assay. Plasma samples were analyzed using commercial ${ }^{125} \mathrm{I}$ corticosterone radioimmunoassays according to the manufacturer's instructions (MP Biochemicals, LLC, Orangeburg, N.Y., USA). The intra- and interassay coefficients of variation were both $7 \%$.

Tissue Processing, Immunohistochemistry, and Microscope

Analysis

Fixed brains were coronally sectioned at $40 \mu \mathrm{m}$ into three series using a cryostat (Microm HM505E, MICROM International GmbH, Walldorf, Germany) and processed for immunohistochemical detection of vasopressin, oxytocin, and GR. Briefly, sections were rinsed in PBS, and incubated in 4\% normal goat serum in PBS with $0.4 \%$ Triton X-100. Next, sections were incubated overnight with primary antibodies for vasopressin (1:250, gift from Dr. Paul Plotsky), oxytocin (1:5,000, Peninsula Lab, San Carlos, Calif., USA) or GR (1:400, M-20, Santa Cruz Biotechnology, Dallas, Tex., USA) in 4\% normal goat serum in PBS with $0.4 \%$ Triton X-100. The next day, tissue sections were washed in PBS, incubated for $2.5 \mathrm{~h}$ in donkey anti-rabbit Alexa 488 (1:200) in 4\% normal goat serum in PBS with $0.4 \%$ Triton $\mathrm{X}-100$ and again rinsed in PBS. Immunohistochemistry was performed separately for P20 and P90 tissues.

Analysis of vasopressin, oxytocin, and GR immunoreactivity was performed using an Olympus IX81 confocal microscope 
equipped with Slidebook software. Images of hippocampal regions (CA1, CA2, CA3, dentate gyrus) were captured bilaterally within three sections (Bregma -1.82 to -2.18 ) using a $\times 20$ objective (UPlan FL, Olympus). Three bilateral sections containing PVN (Bregma -0.7 to -1.06 ) and central amygdala (Bregma -1.06 to -1.34 ) were captured using a $\times 10$ objective (UPlan FL, Olympus). GR immunoreactivity was quantified bilaterally within fixed area frames: CA1 (box, $160 \times 55 \mu \mathrm{m}$ ), CA2 (box, $160 \times 55 \mu \mathrm{m}$ ), CA3 ( 2 boxes, $77 \times$ $93 \mu \mathrm{m}$ each), dentate gyrus ( 2 boxes, $77 \times 93 \mu \mathrm{m}$ each), PVN (circle, $170 \mu \mathrm{m}$ diameter), central amygdala (circle, $270 \mu \mathrm{m}$ diameter). Background threshold levels were set and applied to all images for comparison. Pixel intensities above this threshold were used for quantification measures (area occupied by pixels). Since immunohistochemistry was performed separately for P20 and P90 sections, background threshold levels also varied between these groups. Therefore, these two time points were analyzed separately. For vasopressin and oxytocin analyses, area occupied by vasopressin immunoreactivity was quantified within the entire $\times 10$ image which encompassed the PVN. A frame was not used for this analysis since vasopressin and oxytocin immunoreactivity is not seen in regions in close proximity to the PVN as is the case for GR. For cell quantification, vasopressin- and oxytocin-immunoreactive cells were counted within three sections of each animal (Bregma -0.7 to -1.06 ). For vasopressin and oxytocin, immunoreactive cells were quantified to determine whether MA alters the number of these cell phenotypes in the PVN. This analysis was performed based on a previous study which indicated that developmental stressors can alter the number of cells expressing these phenotypes in the PVN [20]. To determine total immunoreactivity of these proteins in the PVN (cell body and fiber labeling), the area occupied by vasopressin/oxytocin was also quantified. Evidence suggests that stress/glucocorticoids alter GR by decreasing the content within the cell rather than affecting the number of cells expressing GR [34-36]. Therefore, area occupied by GR immunoreactivity measures were utilized to quantify changes in content reflected by differences in labeling intensity. Furthermore, the high density of GR-immunoreactive cells in these regions (particularly the hippocampus) impeded accurate cell counting.

\section{Statistical Analyses}

Data were analyzed with GraphPad Prism v.4 software (San Diego, Calif., USA) using independent t tests (MA vs. saline) for each brain region analyzed in P20 and P90 mice. Since multiple regions within the hippocampus were measured, a repeated-measures ANOVA was performed using SPSS v.16.0 software (Chicago, Ill., USA) to compare GR across treatment and hippocampal regions. As indicated above, age comparisons were not performed since tissues were collected separately and immunohistochemistry was also performed at different times which led to slight variations in labeling intensity and background levels. Corticosterone levels were analyzed using 2-way ANOVA with treatment (MA, saline) and time $(60,120,240 \mathrm{~min})$ as factors. Bonferroni comparisons were used for post hoc analyses of plasma corticosterone levels.

\section{Results}

\section{Corticosterone}

A 2-way ANOVA indicated a main effect of treatment with MA-treated P11 mice showing greater corticoste-

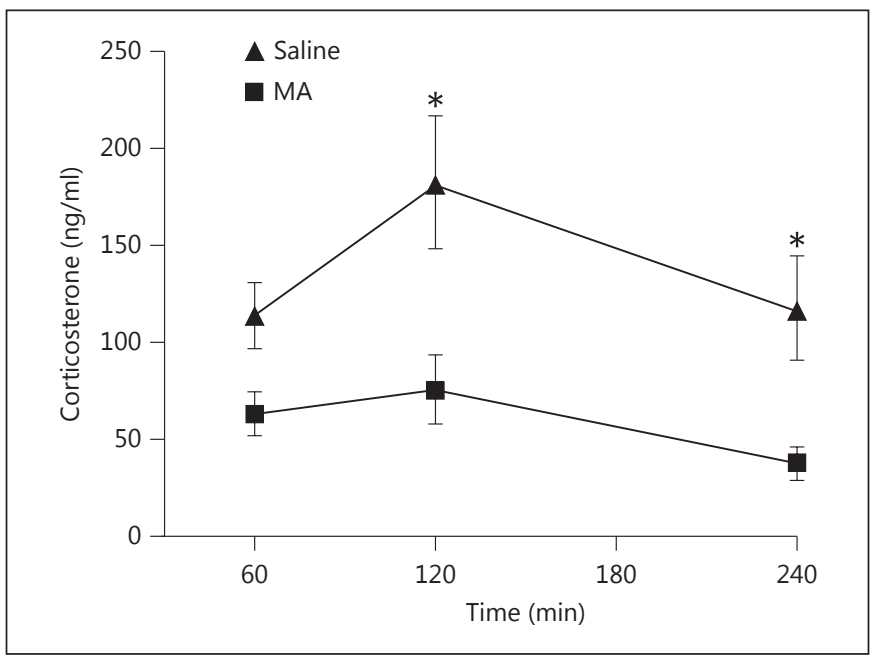

Fig. 1. Corticosterone response to MA treatment. Plasma corticosterone levels were significantly increased in P11 mice injected with MA $(5 \mathrm{mg} / \mathrm{kg})$ compared to saline-injected controls $(\mathrm{p}<0.001)$. Post hoc comparisons revealed significant elevations at 120 and 240 min after MA injection $(\mathrm{p}<0.05)$. Shown as mean \pm SEM. ${ }^{*} \mathrm{p}<0.05$.

rone levels than saline-treated mice $[\mathrm{F}(1,29)=21.07, \mathrm{p}<$ $0.0001]$. Post hoc comparisons revealed significantly higher corticosterone levels in MA-treated than salinetreated mice at 120 and $240 \mathrm{~min}(\mathrm{p}<0.05$; fig. 1). There was also a marginal main effect of time $[\mathrm{F}(1,29)=3.28$, $\mathrm{p}<0.052$ ] which indicated greatest plasma corticosterone levels at $2 \mathrm{~h}$ after administration. There was no significant interaction between treatment and time.

\section{Vasopressin}

Vasopressin immunoreactivity in the mouse brain was consistent with the known distribution which includes extensive immunoreactivity in the PVN, supraoptic nucleus, and suprachiasmatic nucleus [36]. Within the PVN, labeling was found in both magnocellular and parvocellular populations, as described $[37,38]$. The number of vasopressin-immunoreactive cells in the PVN also appeared to increase slightly with age, which corresponds to reports which indicate that vasopressin in the rodent brain continues to develop during the postnatal period [39]. At P20, there was a significant decrease in the number of cells expressing vasopressin $[\mathrm{t}(9)=4.33$; $\mathrm{p}<0.01]$ and the area occupied by vasopressin immunoreactivity in the PVN of MA-treated mice $[\mathrm{t}(9)=2.31 ; \mathrm{p}<0.05$; fig. 2a-d]. At P90, there was still a significant decrease in the number of vasopressin-expressing cells $[\mathrm{t}(9)=2.34$; $\mathrm{p}<0.05]$, but the area of the PVN occupied by vasopressin did not significantly differ by treatment (fig. 2e-h). 


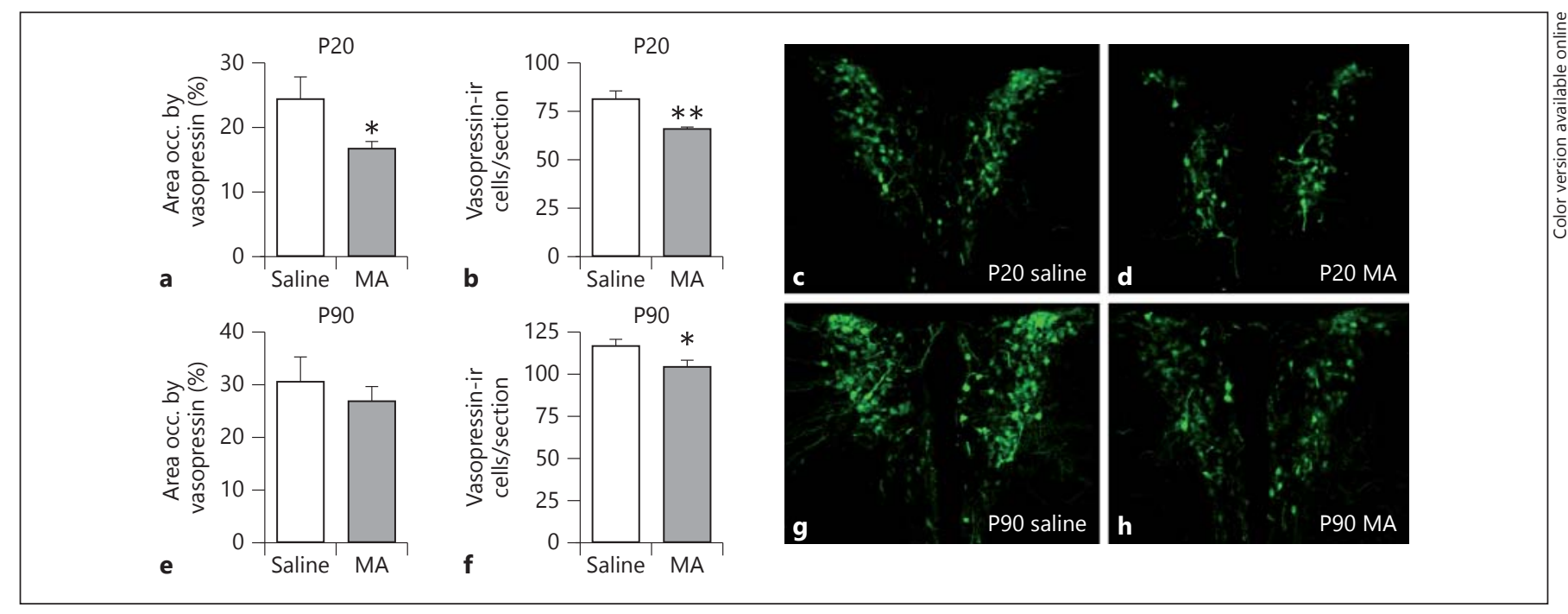

Fig. 2. Vasopressin immunoreactivity in the PVN following postnatal MA treatment. The number of vasopressin-immunoreactive cells (b) and area occupied by vasopressin immunoreactivity (a) was decreased in the PVN of P20 mice treated with MA from P11 to P20 compared to saline controls. At P90 (f), the number of vasopressinimmunoreactive cells was still decreased following MA treatment,

\section{Oxytocin}

Oxytocin immunoreactivity in the mouse brain was similar to previous reports with extensive cell and fiber labeling in the PVN (both parvocellular and magnocellular) and supraoptic nucleus $[20,40]$. The rostrocaudal extent of oxytocin through the PVN was greater than that for vasopressin, with greater oxytocin immunoreactivity found in rostral aspects of the PVN as previously described in rodents [41]. There was no effect of MA treatment in the PVN on the number of oxytocin-expressing cells or the area occupied by oxytocin immunoreactivity at either P20 or P90 (fig. 3).

\section{Glucocorticoid Receptor}

The distribution of GR immunolabeling reported was similar to the distribution previously reported in mice, with high levels of GR in CA1, CA2, and the PVN, and low levels in CA3 [42, 43] (fig. 4, 5). No significant effects of MA were found on GR immunoreactivity in the PVN of P20 or P90 mice (fig. 4). Repeated-measures ANOVA of GR across hippocampal brain regions revealed a significant effect of region at $\mathrm{P} 20[\mathrm{~F}(3,27)=50.00, \mathrm{p}<0.001]$ and $\mathrm{P} 90[\mathrm{~F}(3,27)=90.17, \mathrm{p}<0.001]$ indicating less $\mathrm{GR}$ immunoreactivity in the $\mathrm{CA} 3$ region of the hippocampus compared to other regions (fig. 5). No effects of MA treatment or treatment $\times$ region interaction were found for but the area occupied by vasopressin immunoreactivity did not significantly differ between treatment groups (e). Representative images of vasopressin immunoreactivity in the PVN are shown in $\mathbf{c}, \mathbf{d}$, $\mathbf{g}$, and $\mathbf{h}$. Images were captured using a $\times 10$ objective. Each bar represents the mean \pm SEM. ${ }^{*} \mathrm{p}<0.05,{ }^{* *} \mathrm{p}<0.01$ compared to saline treatment. Area occ. $=$ Area occupied; ir $=$ immunoreactive.

GR immunoreactivity in the hippocampus (fig. 5). In the central nucleus of the amygdala, the area occupied by GR immunoreactivity was significantly decreased by MA at P20 $[\mathrm{t}(9)=2.41 ; \mathrm{p}<0.05$; fig. 6]. This effect was transient, as at P90 GR immunoreactivity was comparable in MAand saline-treated mice (fig. 6).

\section{Discussion}

In this study, we report that developmental exposure to MA, which induces hyperactivation of the HPA axis, results in short- and long-term alterations in HPA axisassociated proteins. Specifically, vasopressin-immunoreactive cells in the PVN were significantly decreased, both at P20 and P90 following postnatal MA treatment. On the contrary, oxytocin and GR immunoreactivity were largely unaffected by MA treatment although GR was transiently decreased by MA in the central nucleus of the amygdala.

The decrease in vasopressin-immunoreactive cells in the PVN may be one mechanism through which the HPA axis and associated stress-related behaviors are altered following developmental exposure to MA. Although long-term effects of neonatal MA exposure on stress hormone release have not been assessed in mice, neonatal 


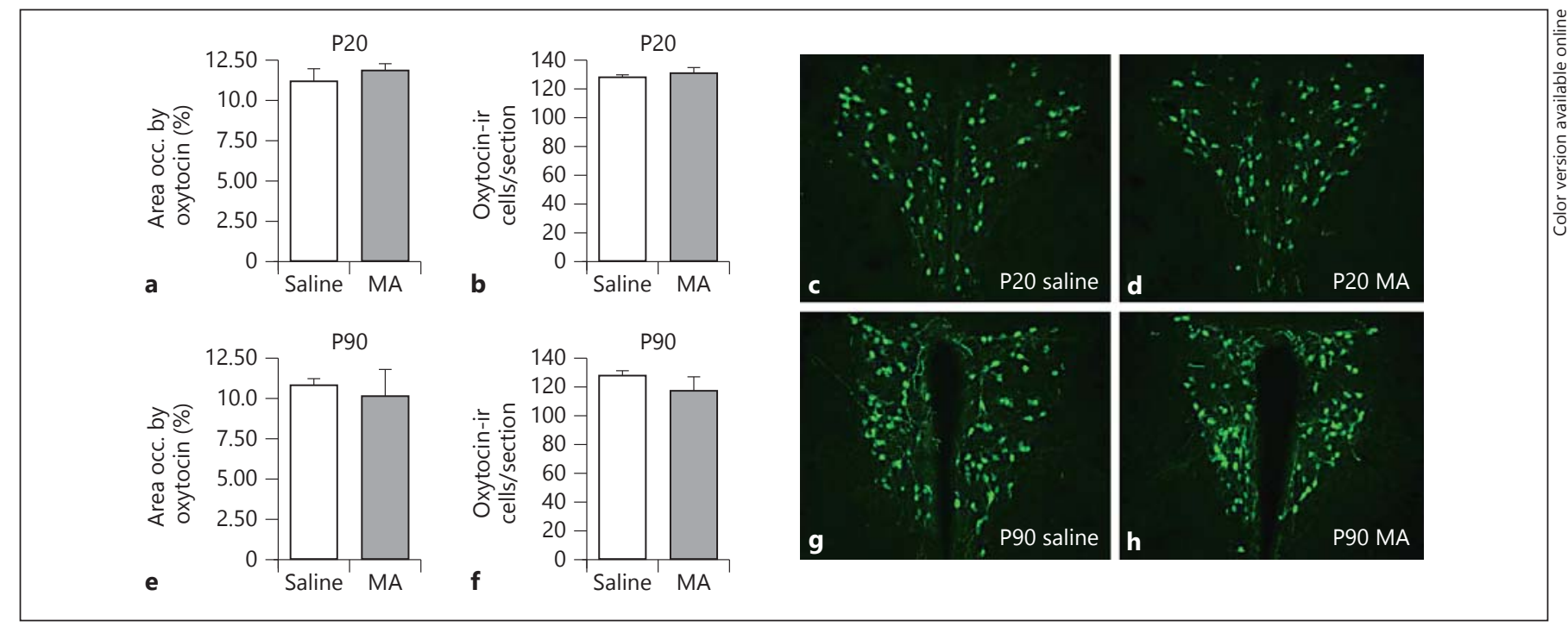

Fig. 3. Oxytocin immunoreactivity in the PVN following postnatal MA treatment. The number of oxytocin-immunoreactive cells (b) and area occupied by oxytocin immunoreactivity (a) was unaffected in the PVN of P20 mice treated with MA from P11 to P20 compared to saline controls. At P90, there were no effects of MA treatment on the number of oxytocin-immunoreactive cells $(\mathbf{f})$ or area occupied by oxytocin (e). Representative images of oxytocinimmunoreactivity in the PVN are shown in $\mathbf{c}, \mathbf{d}, \mathbf{g}$, and $\mathbf{h}$. Images were captured using a $\times 10$ objective. Each bar represents the mean \pm SEM. Area occ. $=$ Area occupied; ir $=$ immunoreactive.
Fig. 4. GR immunoreactivity in the PVN following postnatal MA treatment. The area occupied by GR immunoreactivity was not significantly altered by MA treatment at P20 (a) or P90 (d). Representative images of GR immunoreactivity in the P20 and P90 PVN are shown in $\mathbf{b}, \mathbf{c}, \mathbf{e}$, and $\mathbf{f}$. There was a marginal, although not significant, decrease in GR immunoreactivity in MA-treated mice. Images were captured using a $\times 10$ objective. Each bar represents the mean \pm SEM. Area occ. $=$ Area occupied.

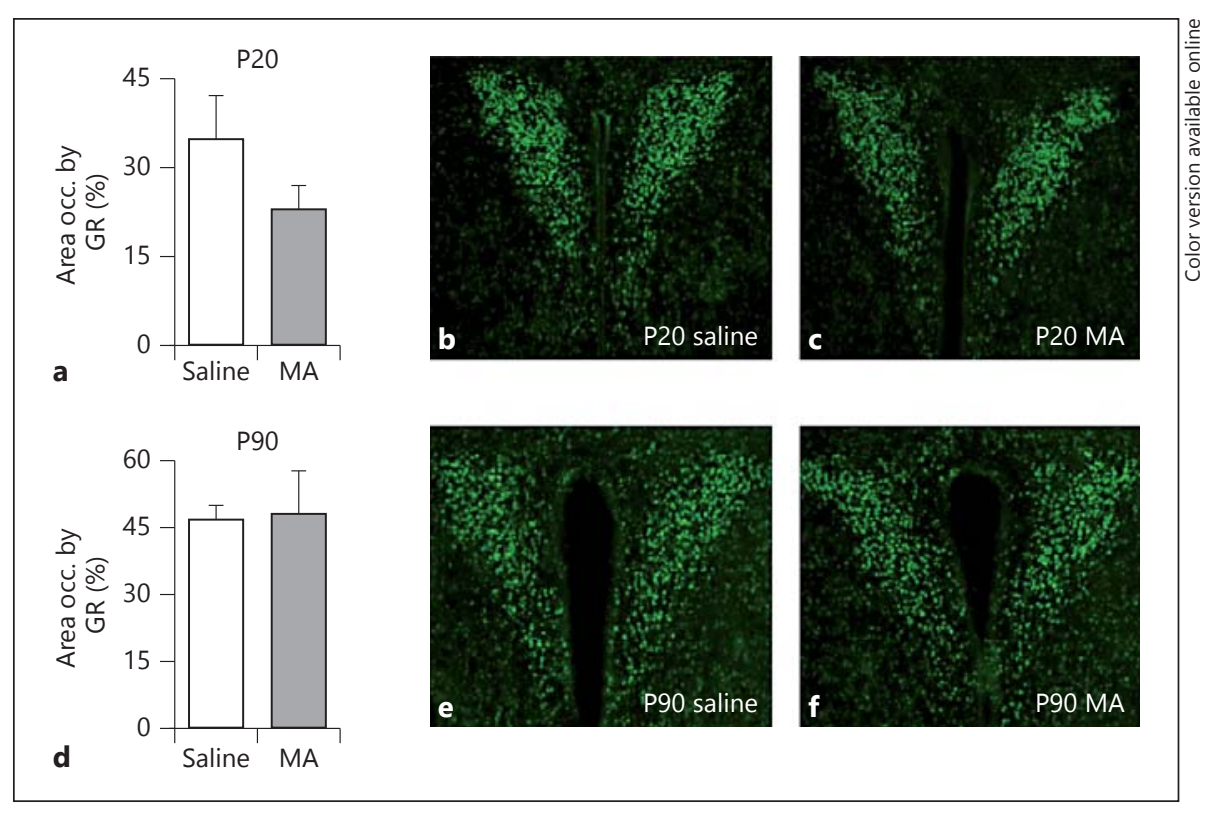

MA treatment in rats has been shown to decrease the release of corticosterone following adult exposure to the forced swim test [30], indicating a blunted HPA axis response to stress. A decrease in the number of vasopressinimmunoreactive cells in the PVN may contribute to this effect since this cell phenotype is involved in HPA axis activation [44]. Furthermore, since glucocorticoid release is involved in cognitive behaviors including learning and memory [45], a decrease in vasopressin may contribute to alterations in these functions. Exposure to MA during the 
Fig. 5. GR immunoreactivity in the hippocampus following postnatal MA treatment. The area occupied by GR immunoreactivity was not significantly altered by MA treatment in any region of the hippocampus at P20 (a) or P90 (b). c, d Representative images of GR immunoreactivity in the P20 hippocampus. Boxes indicate areas within which GR immunoreactivity was quantified. Images were captured using a $\times 4$ objective. Each bar represents the mean \pm SEM. Den $=$ Dentate gyrus. Area occ. $=$ Area occupied .

Fig. 6. GR immunoreactivity in the central amygdala following postnatal MA treatment. The area occupied by GR immunoreactivity was significantly decreased following MA treatment at P20 (a), with no differences found at P90 (d). Representative images of GR immunoreactivity in the central nucleus of the amygdala at P20 and $\mathrm{P} 90$ are shown in $\mathbf{b}, \mathbf{c}, \mathbf{e}$, and $\mathbf{f}$. Boxes indicate areas within which GR immunoreactivity was quantified. Images were captured using a $\times 10$ objective. Each bar represents the mean \pm SEM. ${ }^{*} \mathrm{p}<0.05$. Area occ. $=$ Area occupied.
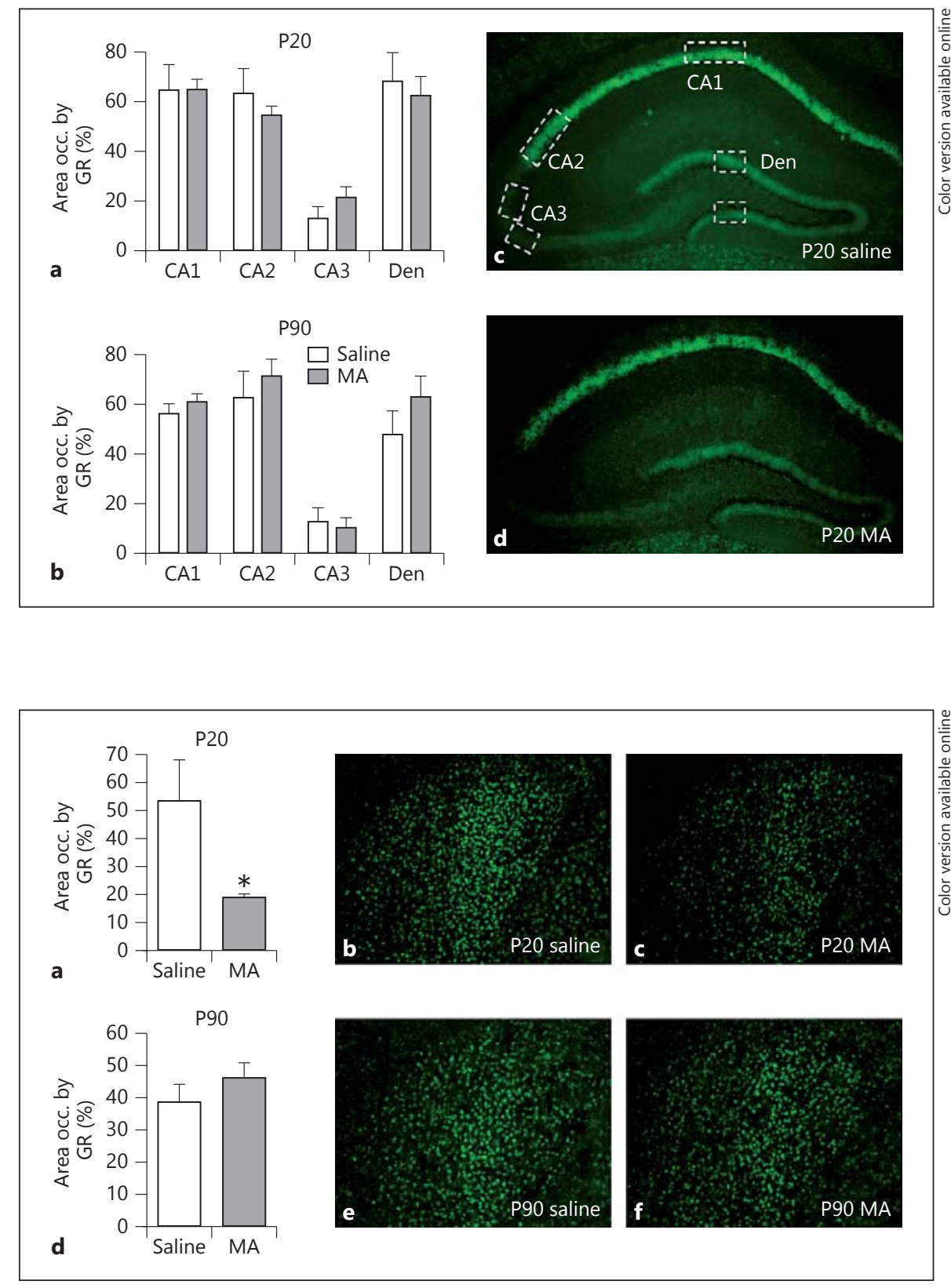

same neonatal treatment period used in this study results in learning and memory deficits both in adolescent [27] and adult mice [31]; therefore, an alteration in central vasopressin may be one mechanism through which MA induces these alterations. Similar to results presented here, neonatal maternal separation also results in decreases in vasopressin immunoreactivity in 4- and 6-week-old mice [20]. Since both maternal separation and MA treatment involve early increases in corticosterone $[5,46]$, this excess exposure to corticosterone could be the mechanism through which the number of vasopressin-immmunoreactive cells is altered. Further studies are warranted to test this possibility.

One possible mechanism through which MA can decrease vasopressin-immunoreactive cells in the PVN is by increasing cell death in vasopressin cells. MA has previously been reported to increase cell death in several brain regions $[47,48]$, although the PVN has not yet been examined. Vasopressin-immunoreactive cells have been reported to co-localize with GR, particularly following in- 
stances of excessive glucocorticoid exposure [49, 50]. Therefore MA-induced glucocorticoids may act directly on vasopressin-immunoreactive cells to induce alterations. Vasopressin cells in the PVN may be particularly vulnerable to alterations from P11 to P20 since this is an important developmental period for vasopressin immunoreactivity. Vasopressin content in the rodent PVN increases from P15 to P30 [51].

Unlike vasopressin, oxytocin expression in the PVN was unaffected by MA treatment indicating that oxytocin may be less vulnerable to developmental MA-induced alterations. At present, little is known about short- or longterm effects of developmental MA or glucocorticoid exposure on the brain oxytocin system although a study in sheep indicates that prenatal exposure to glucocorticoids fails to alter oxytocin mRNA in the pituitary gland [52]. However, social isolation after weaning has been shown to increase oxytocin mRNA levels in the PVN [53] and maternal separation increases the number of oxytocinimmunoreactive cells in the PVN [20]. Both of these procedures increase glucocorticoid levels although it is unknown whether this is the cause of these oxytocin alterations. The lack of evidence regarding developmental glucocorticoid treatment-induced alterations in oxytocin and the data presented here which indicate no effects on PVN oxytocin expression suggest that an alternative mechanism may be involved.

GR was unaffected by MA in the PVN and hippocampus. This indicates that GR expression in these regions may be minimally vulnerable to dysregulation following developmental MA exposure. Alterations in GR by MA have been reported previously in rats. Kabbaj et al. [54] reported that chronic MA treatment in adult rats alters GR mRNA levels in the hippocampus in one strain (Fischer 344) but not another (Lewis). In another study, repeated administration of MA to Sprague-Dawley rats significantly decreased GR mRNA levels in the hippocampus and hypothalamus 6 days after treatment [55]. The absence of an effect of MA on GR immunoreactivity in the hippocampus and PVN reported here may therefore indicate that the genetic background might modulate sensitivity to MA. It is also possible that exposure to MA during brain development differs from that during adulthood in its effects on GR expression. A higher dose of MA, such as those utilized to induce neurotoxicity [56, 57], may be effective in altering expression of GR and oxytocin, as well as increase effects on vasopressin. Further studies are needed to test this possibility.

In the central nucleus of the amygdala, there was a transient decrease in GR following MA treatment at P20, although this decrease was resolved in adulthood at P90. While prenatal exposure to glucocorticoids has been shown to alter amygdala GR levels in rats [20], to our knowledge, this is the first study in which GR levels were measured following postnatal MA treatment. This raises the possibility that MA-induced increases in glucocorticoids may contribute to the effects reported here in the mouse amygdala at P20. The transient decrease in GR immunoreactivity in the central nucleus of the amygdala in MA-treated mice may contribute to short-term deficits in the HPA axis and associated behaviors. Little is known about possible short-term effects on HPA axis function. Previously, we reported that this treatment regimen fails to alter anxiety-related behaviors, while it does alter aspects of cognition in adolescent mice [27]. These shortterm alterations in central amygdala GR expression may also affect the development of this region and subsequently alter its function in adulthood. Further studies are warranted to test for lasting effects of MA on central amygdala morphology and function.

In summary, there are short- and long-term alterations in vasopressin-immunoreactive cells in the PVN and short-term alterations in GR that are restricted to the central nucleus of the amygdala. These alterations in the expression of HPA axis-associated neuropeptides and receptors may contribute to behavioral and cognitive alterations reported in adolescent and adult rodents as well as humans $[3,26,27,31]$.

\section{Acknowledgements}

Funding was provided by NIDA T32DA007262, an Oregon Health and Science University Tartar Award, and the Oregon Health and Science University development account of Dr. Raber.

References

1 Substance Abuse and Mental Health Services Administration (SAMHSA): Results from the 2009 National Survey on Drug Use and Health. Rockville, Office of Applied Studies, SAMHSA, 2010, vol 1: Summary of National Findings.

2 Piper B, Acevedo SF, Kolchugina GK, Butler RW, Corbett SM, Honeycutt EB, Craytor MJ, Raber J: Abnormalities in parentally rated executive function in methamphetamine/polysubstance exposed children. Pharmacol Biochem Behav 2011;98:432-439.

3 Chang L, Smith LM, LoPresti C, Yonekura ML, Kuo J, Walot I, Ernst T: Smaller subcortical volumes and cognitive deficits in children with prenatal methamphetamine exposure. Psychiatry Res 2004;132:95-106. 
4 LaGasse LL, Derauf C, Smith LM, Newman E, Shah R, Neal C, Arria A, Huestis MA, DellaGrotta S, Lin H, Dansereau LM, Lester BM: Prenatal methamphetamine exposure and childhood behavior problems at 3 and 5 years of age. Pediatrics 2012;129:681-688.

5 Acevedo SF, Pfankuch T, van Meer P, Raber J: Role of histamine in short- and long-term effects of methamphetamine on the developing mouse brain. J Neurochem 2008; 107:976-986.

6 Williams MT, Inman-Wood SL, Morford LL, McCrea AE, Ruttle AM, Moran MS, Rock SL, Vorhees CV: Preweaning treatment with methamphetamine induces increases in both corticosterone and ACTH in rats. Neurotoxicol Teratol 2000;22:751-759.

7 Grace CE, Schaefer TL, Herring NR, Skelton MR, McCrea AE, Vorhees CV, Williams MT: (+)-Methamphetamine increases corticosterone in plasma and BDNF in brain more than forced swim or isolation in neonatal rats. Synapse 2008;62:110-121.

8 Zhu H, Mingler MK, McBride ML, Murphy AJ, Valenzuela DM, Yancopoulos GD, Williams MT, Vorhees CV, Rothenberg ME: Abnormal response to stress and impaired NPS-induced hyperlocomotion, anxiolytic effect and corticosterone increase in mice lacking NPSR1. Psychoneuroendocrinology 2010;35:1119-1132.

9 Söderpalm A, Nikolayev L, de Wit H: Effects of stress on responses to methamphetamine in humans. Psychopharmacology (Berl) 2003; 170:188-199.

10 Nagano M, Ozawa H, Suzuki H: Prenatal dexamethasone exposure affects anxiety-like behaviour and neuroendocrine systems in an age-dependent manner. Neurosci Res 2008; 60:364-371.

11 Brabham T, Phelka A, Zimmer C, Nash A, López JF, Vázquez DM: Effects of prenatal dexamethasone on spatial learning and response to stress is influenced by maternal factors. Am J Physiol Regul Integr Comp Physiol 2000;279:R1899-R1909.

12 Noorlander CW, Visser GH, Ramakers GM, Nikkels PG, de Graan PN: Prenatal corticosteroid exposure affects hippocampal plasticity and reduces lifespan. Dev Neurobiol 2008; 68:237-246

13 Zuloaga DG, Carbone DL, Hiroi R, Chong DL, Handa RJ: Dexamethasone induces apoptosis in the developing rat amygdala in an age-, region-, and sex-specific manner. Neuroscience 2011;199:535-547.

14 Zuloaga DG, Carbone DL, Quihuis AM, Hiroi R, Chong DL, Handa RJ: Perinatal dexamethasone-induced alterations in apoptosis within the hippocampus and paraventricular nucleus of the hypothalamus are influenced by age and sex. J Neurosci Res 2012;90:1403-1412.

15 Fukumoto K, Morita T, Mayanagi T, Tanokashira D, Yoshida T, Sakai A, Sobue K: Detrimental effects of glucocorticoids on neuronal migration during brain development. Mol Psychiatry 2009;14:1119-1131.

16 Rugerio-Vargas C, Ramírez-Escoto M, DelaRosa-Rugerio C, Rivas-Manzano P: Prena- tal corticosterone influences the trajectory of neuronal development, delaying or accelerating aspects of the Purkinje cell differentiation. Histol Histopathol 2007;22:963-969.

17 Banjanin S, Kapoor A, Matthews SG: Prenatal glucocorticoid exposure alters hypothalamicpituitary-adrenal function and blood pressure in mature male guinea pigs. J Physiol 2004;558:305-318.

18 Shoener JA, Baig R, Page KC: Prenatal exposure to dexamethasone alters hippocampal drive on hypothalamic-pituitary-adrenal axis activity in adult male rats. Am J Physiol Regul Integr Comp Physiol 2006;290:1366-1373.

19 Dean F, Matthews SG: Maternal dexamethasone treatment in late gestation alters glucocorticoid and mineralocorticoid receptor mRNA in the fetal guinea pig brain. Brain Res 1999;846:253-259.

20 Tsuda MC, Yamaguchi N, Ogawa S: Early life stress disrupts peripubertal development of aggression in male mice. Neuroreport 2011; 22:259-263.

21 Matthews SG, Owen D, Banjanin S, Andrews MH: Glucocorticoids, hypothalamo-pituitary-adrenal (HPA) development, and life after birth. Endocr Res 2002;28:709-718.

22 Jones RA: Randomized, controlled trial of dexamethasone in neonatal chronic lung disease: 13- to 17-year follow-up study. 1. Neurologic, psychological, and educational outcomes. Pediatrics 2005;116:370-378.

23 Spijker AT, van Rossum EF: Glucocorticoid receptor polymorphisms in major depression. Focus on glucocorticoid sensitivity and neurocognitive functioning. Ann NY Acad Sci 2009;1179:199-215.

24 Egashira N, Mishima K, Iwasaki K, Oishi R, Fujiwara M: New topics in vasopressin receptors and approach to novel drugs: role of the vasopressin receptor in psychological and cognitive functions. J Pharmacol Sci 2009; 109:44-49.

25 Kovács GL, Bohus B, Versteeg DH, de Kloet ER, de Wied D: Effect of oxytocin and vasopressin on memory consolidation: sites of action and catecholaminergic correlates after local microinjection into limbic-midbrain structures. Brain Res 1979;175:303-314.

26 King G, Alicata D, Cloak C, Chang L: Psychiatric symptoms and HPA axis function in adolescent methamphetamine users. J Neuroimmune Pharmacol 2010;5:582-591.

27 Siegel JA, Park BS, Raber J: Long-term effects of neonatal methamphetamine exposure on cognitive function in adolescent mice. Behav Brain Res 2011;219:159-164.

28 Altman J, Bayer SA: Migration and distribution of two populations of hippocampal granule cell precursors during the perinatal and postnatal periods. J Comp Neurol 1990;301: 365-381.

29 Clancy B, Darlington RB, Finlay BL: Translating developmental time across mammalian species. Neuroscience 2001;105:7-17.

30 Williams MT, Blankenmeyer TL, Schaefer TL, Brown CA, Gudelsky GA, Vorhees CV: Long- term effects of neonatal methamphetamine exposure in rats on spatial learning in the Barnes maze and on cliff avoidance, corticosterone release, and neurotoxicity in adulthood. Brain Res Dev Brain Res 2003;147:163-175.

31 Siegel JA, Craytor MJ, Raber J: Long-term effects of methamphetamine exposure on cognitive function and muscarinic acetylcholine receptor levels in mice. Behav Pharmacol 2010;21:602-614.

32 Acevedo SF, de Esch IJ, Raber J: Sex- and histamine-dependent long-term cognitive effects of methamphetamine exposure. Neuropsychopharmacology 2007;32:665-672.

33 Eastwood E, Allen CN, Raber J: Effects of neonatal methamphetamine and thioperamide exposure on spatial memory retention and circadian activity later in life. Behav Brain Res 2012;230:229-236.

34 Kitraki E, Kremmyda O, Youlatos D, Alexis MN, Kittas C: Gender-dependent alterations in corticosteroid receptor status and spatial performance following 21 days of restraint stress. Neuroscience 2004; 125:47-55.

35 Kitraki E, Kremmyda O, Youlatos D, Alexis M, Kittas C: Spatial performance and corticosteroid receptor status in the 21-day restraint stress paradigm. Ann NY Acad Sci 2004;1018: 323-327.

36 Zhe D, Fang H, Yuxiu S: Expressions of hippocampal mineralocorticoid receptor (MR) and glucocorticoid receptor (GR) in the single-prolonged stress-rats. Acta Histochem Cytochem 2008;41:89-95.

37 Rood BD, De Vries GJ: Vasopressin innervation of the mouse (Mus musculus) brain and spinal cord. J Comp Neurol 2011;519:24342474.

38 Rood BD, Stott RT, You S, Smith CJ, Woodbury ME, de Vries GJ: Site of origin of and sex differences in the vasopressin innervation of the mouse (Mus musculus) brain. J Comp Neurol 2013;521:2321-2358.

39 Krisch B: Electron microscopic immunocytochemical investigation on the postnatal development of the vasopressin system in the rat. Cell Tissue Res 1980;205:453-471.

40 Liu HL, Cao R, Jin L, Chen LW: Immunocytochemical localization of substance $\mathrm{P}$ receptor in hypothalamic oxytocin-containing neurons of C57 mice. Brain Res 2002;948:175-179.

41 Swaab DF, Pool CW, Nijveldt F: Immunofluorescence of vasopressin and oxytocin in the rat hypothalamo-neurohypophypopseal system. J Neural Transm 1975;36:195-215.

42 Nishi M, Usuku T, Itose M, Fujikawa K, Hosokawa K, Matsuda KI, Kawata M: Direct visualization of glucocorticoid receptor positive cells in the hippocampal regions using green fluorescent protein transgenic mice. Neuroscience 2007;146:1555-1560.

43 Schmidt MV, Oitzl MS, Müller MB, Ohl F, Wurst W, Holsboer F, Levine S, De Kloet ER: Regulation of the developing hypothalamicpituitary-adrenal axis in corticotropin releasing hormone receptor 1-deficient mice. Neuroscience 2003;119:589-595. 
44 Dyball RE, Koizumi K: Electrical activity in the supraoptic and paraventricular nuclei associated with neurohypophysial hormone release. J Physiol 1969;201:711-722.

45 Roozendaal B, McGaugh JL: Amygdaloid nuclei lesions differentially affect glucocorticoid-induced memory enhancement in an inhibitory avoidance task. Neurobiol Learn Mem 1996;65:1-8.

46 Kuhn CM, Pauk J, Schanberg SM: Endocrine responses to mother-infant separation in developing rats. Dev Psychobiol 1990;23:395410.

47 Krasnova IN, Cadet JL: Methamphetamine toxicity and messengers of death. Brain Res Rev 1999;60:379-407.

48 Deng X, Wang Y, Chou J, Cadet JL: Methamphetamine causes widespread apoptosis in the mouse brain: evidence from using an improved TUNEL histochemical method. Brain Res Mol Brain Res 2001;93:64-69.
49 Uht RM, McKelvy JF, Harrison RW, Bohn MC: Demonstration of glucocorticoid receptor-like immunoreactivity in glucocorticoidsensitive vasopressin and corticotropin-releasing factor neurons in the hypothalamic paraventricular nucleus. J Neurosci Res 1988 ; 19:405-411, 468-469.

50 de Souza LM, Franci CR: Differential immunoreactivity of glucocorticoid receptors and vasopressin in neurons of the anterior and medial parvocellular subdivisions of the hypothalamic paraventricular nucleus. Brain Res Bull 2010;82:271-278.

51 van Tol HH, Snijdewint FG, Boer GJ, Burbach JP: Postnatal development of vasopressin mRNA content in supraoptic and paraventricular nucleus of the Wistar rat. Neurosci Lett 1986;65:1-6.

52 Sloboda DM, Newnham JP, Challis JR: Effects of repeated maternal betamethasone administration on growth and hypothalamic-pituitary-adrenal function of the ovine fetus at term. J Endocrinol 2000;165:79-91.

53 Pan Y, Liu Y, Young KA, Zhang Z, Wang Z: Post-weaning social isolation alters anxietyrelated behavior and neurochemical gene expression in the brain of male prairie voles. Neurosci Lett 2009;454:67-71.
54 Kabbaj M, Yoshida S, Numachi Y, Matsuoka H, Devine DP, Sato M: Methamphetamine differentially regulates hippocampal glucocorticoid and mineralocorticoid receptor mRNAs in Fischer and Lewis rats. Brain Res Mol Brain Res 2003;117:8-14.

55 Lowy MT, Novotney S: Methamphetamineinduced decrease in neural glucocorticoid receptors: relationship to monoamine levels. Brain Res 1994;638:175-181.

56 Vorhees CV, Skelton MR, Grace CE, Schaefer TL, Graham DL, Braun AA, Williams MT: Effects of $(+)$-methamphetamine on path integration and spatial learning, but not locomotor activity or acoustic startle, align with the stress hyporesponsive period in rats. Int J Dev Neurosci 2009;27:289-298.

57 Deng X, Wang Y, Chou J, Cadet JL: Methamphetamine causes widespread apoptosis in the mouse brain: evidence from using an improved TUNEL histochemical method. Brain Res Mol Brain Res 2001;93:64-69. 